\title{
RADIOCARBON DATING THE “WILDERNESS OF ZIN”
}

\author{
Hendrik J Bruins
}

Ben-Gurion University of the Negev, The Jacob Blaustein Institutes for Desert Research, Department of Man in the Desert, Sede Boker Campus, Israel. Email: hjbruins@bgu.ac.il.

\section{Johannes van der Plicht}

University of Groningen, Centre for Isotope Research, Nijenborgh, Groningen, the Netherlands; and Leiden University, Faculty of Archaeology, Leiden, the Netherlands. Email: J.van.der.Plicht@rug.nl.

\begin{abstract}
An important archaeological survey was conducted by Leonard Woolley and T E Lawrence in 1914 on behalf of the Palestine Exploration Fund in the Negev and northeastern Sinai deserts-the "Wilderness of Zin." The region of Ain Kadeis, associated by some scholars in the 19th century with biblical Kadesh-Barnea, received much attention in their survey and discussions. Concerning the vexed question of Kadesh-Barnea, Woolley and Lawrence gave their preference for the nearby Ain el Qudeirat ${ }^{1}$ Valley, and in particular the ancient tell. Their survey contributed significantly in the shaping of scholarly opinion on the matter, even until today. But modern surveys and excavations failed to identify any archaeological remnants of the 2 nd millennium BCE in the above regions, thereby putting the above associations in question. The Middle Bronze Age II, Late Bronze Age, and Iron Age I that cover this millennium are considered missing in the area in archaeological terms. However, our research reveals that archaeological remains of the 2nd millennium BCE do exist in the region, as determined chronologically by radiocarbon dating. A geoarchaeological approach is required to investigate terraced fields in wadis, which contain a unique record of human activity in these desert regions.
\end{abstract}

\section{INTRODUCTION}

As the First World War was approaching, Woolley and Lawrence received instructions from British Military Intelligence to suspend their archaeological excavations at Carchemish in northern Syria at the end of 1913, in order to conduct an archaeological survey of the Negev and the Arabah ${ }^{2}$ Valley (Figure 1). The latter areas were part of the Turkish Ottoman Empire at the time, while Egypt and Sinai were controlled by the British Empire. The now famous archaeological survey was carried out during January and February of 1914 on behalf of the Palestine Exploration Fund. It served as a cover for British military mapping of this border region, and Captain Newcombe, director of the survey, headed the operation.

Mapping is indeed an integral part of archaeological surveying. The professional scholarship of Woolley and Lawrence led to a remarkable amount of archaeological data and recordings of monuments in the Negev, northeastern Sinai, and the Arabah Valley during a period of only 6 weeks. The resulting publication appeared in 1915 in a double volume of the Annual of the Palestine Exploration Fund for 1914-1915. The archaeological aims of the survey were summarized by Lawrence in the introduction:

The main objects that we had in view were four: to get some idea of the character of the country in successive periods; to trace the Darb el Shur, the old inland route of caravans from central Palestine to Egypt; to identify sites mentioned in the Bible and other historical writings; and, though this lay outside the limits of the new survey, to study the neighbourhood of Ain Kadeis, supposed to be the Kadesh-Barnea of the Israelite wanderings (Woolley and Lawrence 1914-1915:xiv).

\footnotetext{
'Qudeirat is spelled as Guderat in the publication by Woolley and Lawrence (1914-1915) and in other papers. We use the most common modern spelling of Qudeirat.

${ }^{2}$ Arabah is also spelled Arava.
} 
The latter aim was clearly considered of particular interest by the authors, as reflected by the title chosen for their book-The Wilderness of Zin - the biblical name for the desert adjacent to KadeshBarnea. There may even have been a touch of humor in the selection of their title in relation to the geographic intelligence gathering and military mapping aspects of their survey, as it is written in Numbers 13:21, "So they went up and spied out the land from the Wilderness of Zin...".

Concerning their archaeological findings and conclusions, it is clear that a survey of just 6 weeks cannot lead to perfect results. Some of the errors were pointed out by Rosen (2002), who also emphasized the great value of the book. Indeed, the work of Woolley and Lawrence gives an important picture of the region as it appeared in 1914 just before the onset of vast geopolitical changes that began with the First World War. Their geographical and anthropological observations are important, as well as their descriptions and photographs of archaeological sites before modern excavations and development in the region led to considerable changes.

The possible location of Kadesh-Barnea features prominently in their book, as Woolley and Lawrence evaluated the scholarly debate in those days concerning the spring of Ain Kadeis. They visited this area during their survey and rejected it as a candidate, but expressed strong preference for the nearby area of Ain el Qudeirat. Their treatment of the subject and their viewpoints proved very important in the shaping of subsequent scholarly opinion concerning the location of biblical Kadesh-Barnea in the area of Ain el Qudeirat.

However, modern archaeological surveys and excavations in the "Wilderness of Zin" area (northeastern Sinai and the central Negev) by Rudolph Cohen and his team of archaeologists failed to identify any remnants of the 2nd millennium BCE (Cohen 1981a,b,c, 1986, 1993a,b, 1999; Haiman 1986, 1991, 1993, 1994, 1996, 1999, 2003; Avni 1992; Rosen 1994; Cohen and CohenAmin 2004). The Middle and Late Bronze ages, as well as the Early Iron Age, which cover this millennium, are considered missing in this region in archaeological terms. These results pose a serious problem, questioning any of the above associations with Kadesh-Barnea and the emergence of Israel in relation to literary sources.

The Exodus and desert wanderings are highly controversial and enigmatic subjects in relation to archaeology and history, today even more so than before the First World War. The earliest mention of Israel in extra-biblical texts is on the Merneptah Stele (Hasel 1994), discovered in 1896 by Flinders Petrie at Thebes in the mortuary temple of Pharaoh Merneptah, who ruled Egypt from 1212-1202 BCE. The stele has been dated to around 1210-1207 BCE, relating to military campaigns by Merneptah, the son of Ramses II. Many scholars accept that Israel, according to the stele, was an established ethnic group in the region in temporal terms at least by the late 13th century BCE (Shanks et al. 1992). Various scholars place the emergence of Israel roughly at the transition between the Late Bronze Age and Iron Age. Historical information about tribal groups living in Canaan in the Late Bronze Age are found in the Amarna Letters, a corpus of clay tablets found in Egypt dating to the period of 1386-1321 BCE (Moran 1992; Redford 1992; Goren et al. 2004). Suggested relationships between the Apiru/Habiru of the Amarna Letters and the biblical Hebrews are disputed. Ancient historians such as Josephus Flavius placed the origins of Israel even further back into the 2nd millennium BCE-a view that was adopted by many scholars prior to the 1970 s (cf. Epstein 1960). A review of the range of scholarly opinion concerning the biblical history and emergence of Israel is far beyond the scope of this article, but it is one of the most difficult archaeological and historical problems (Mazar 1993; Dever 1995; Stager 1998; Malamat 2001).

Possible associations of archaeological findings in the Wilderness of Zin region with the above issues require at least a temporal relationship in the broadest terms with the 2 nd millennium BCE. 
But this millennium is considered absent in the region according to conventional archaeological dating and understanding.

The research presented here shows that radiocarbon dating does give evidence of archaeological remains in this region belonging to the 2 nd millennium BCE. Indeed, in detached theoretical terms it seems inconceivable, first, that people would not have ventured into this area-where springs and relatively high altitude give ecological advantages in terms of land use-and second, did not leave any remains whatsoever during the entire Middle Bronze Age II ( 2000-1550), the Late Bronze Age ( 1550-1200), and the Iron Age I ( 1200-1000) (see Ben-Tor [1992] for a general chronological overview). Independent dating based on ${ }^{14} \mathrm{C}$ and refined geoarchaeological approaches are required to find such evidence (Bruins and van der Plicht 2004, 2005; Bruins 2005).

The time boundary between Iron Age I and Iron Age II, around the end of the 2nd millennium BCE, is a hotly debated topic (cf. Finkelstein 2005a; Levy and Higham 2005; Mazar 2005) in which archaeological, historical, biblical, and ${ }^{14} \mathrm{C}$ considerations play a role. Mazar (2005) proposed to place the boundary around the millennium transition, at $980 \mathrm{BCE}$. The detailed ${ }^{14} \mathrm{C}$ dating record of Tel Rehov (Bruins et al. 2003a,b, 2005b; Mazar et al. 2005) supports such a viewpoint.

The conclusions by Gilboa and Sharon (2001, 2003), Finkelstein and Piasetzky (2003), Boaretto et al. (2005), and Sharon et al. (2007) to place the ${ }^{14} \mathrm{C}$ boundary of the Iron Age I/II transition in the 9th century or around $900 \mathrm{BCE}$ are not corroborated by our dates from Tel Rehov (Bruins et al. 2003a,b, 2005b; Mazar et al. 2005), from Tel Dan (Bruins et al. 2005a), and from sites in the Negev and Sinai (Bruins and van der Plicht 2005). The results of the Bayesian sequence analysis of Tel Rehov are particularly convincing: the highest relative probability of the ${ }^{14} \mathrm{C}$ boundary between Iron IB and Iron IIA at Tel Rehov is 992-961 BCE (Bruins et al. 2005b). The Tel Rehov results are based on the largest number of short-lived, high-quality dates obtained so far for any single Iron Age site in the Near East, measured by both gas proportional counting (GPC) and accelerator mass spectrometry (AMS) at Groningen. However, the subject of ${ }^{14} \mathrm{C}$ dates regarding the Iron Age I/II transition is not the main subject of the current article and will be discussed in more detail elsewhere.

\section{THE WILDERNESS OF ZIN AND KADESH-BARNEA}

The English term "wilderness" is the more poetic translation of the Hebrew word midbar, meaning "desert." The practical constraints of a desert area in human terms are related to its dryness. Aridity renders it unsuitable for rainfed agriculture, though extensive livestock grazing (pastoralism) is often feasible (Bruins and Berliner 1998). There are a great number of different desert landscapes in the southern Levant, within the modern regions of Sinai, the Negev, and southwestern Jordan. The non-technical nature or non-diagnostic wording of the biblical text in modern scientific terms make it often very difficult to locate the precise position of biblical desert regions and place names. Various geographic options may be available that could fit the ancient texts.

Moreover, modern usage of biblical geographic names can be confusing with respect to their ancient location. The term Sinai at present covers the entire peninsula up to the political boundary with the Negev. This boundary was demarcated as the border between the Turkish Empire and Egypt in 1906 (Figure 1), following an agreement between Britain and Turkey. The location of this boundary does not follow landmarks or physical geographic attributes and is, therefore, of no significance in an archaeological-historical sense. The same boundary line is used at present as the international border between Egypt and Israel. 
Map I.

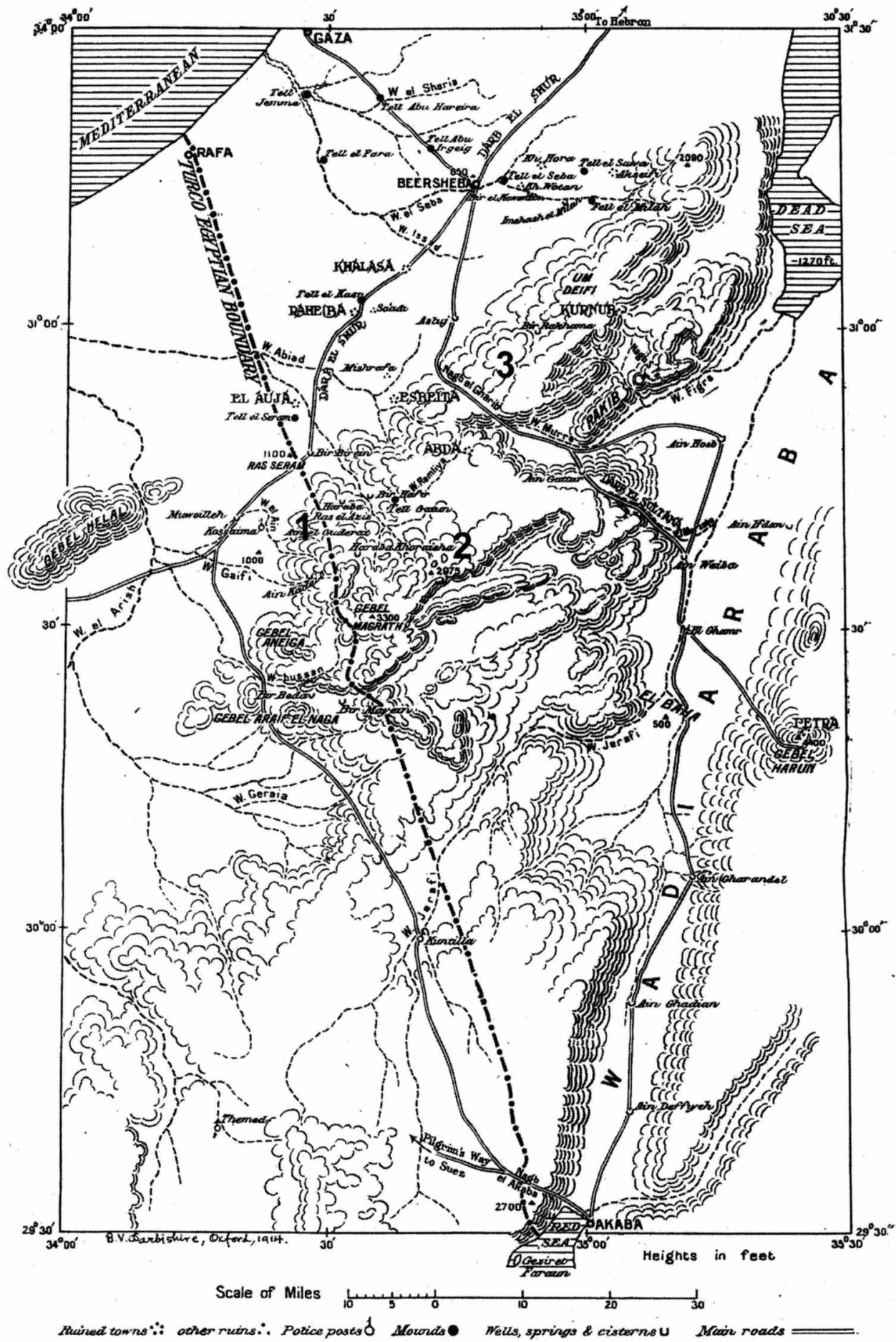

Figure 1 Map of the Negev, Arabah Valley, and northeastern Sinai, as published in The Wilderness of Zin by Woolley and Lawrence (1914-1915). Inserted numbers: 1 = Ain el Qudeirat Valley and Tell el Qudeirat; 2 = Ha'Elah Fortress; and 3 = Horvat Haluqim. Permission to reprint courtesy of the Palestinian Exploration Fund, London. 


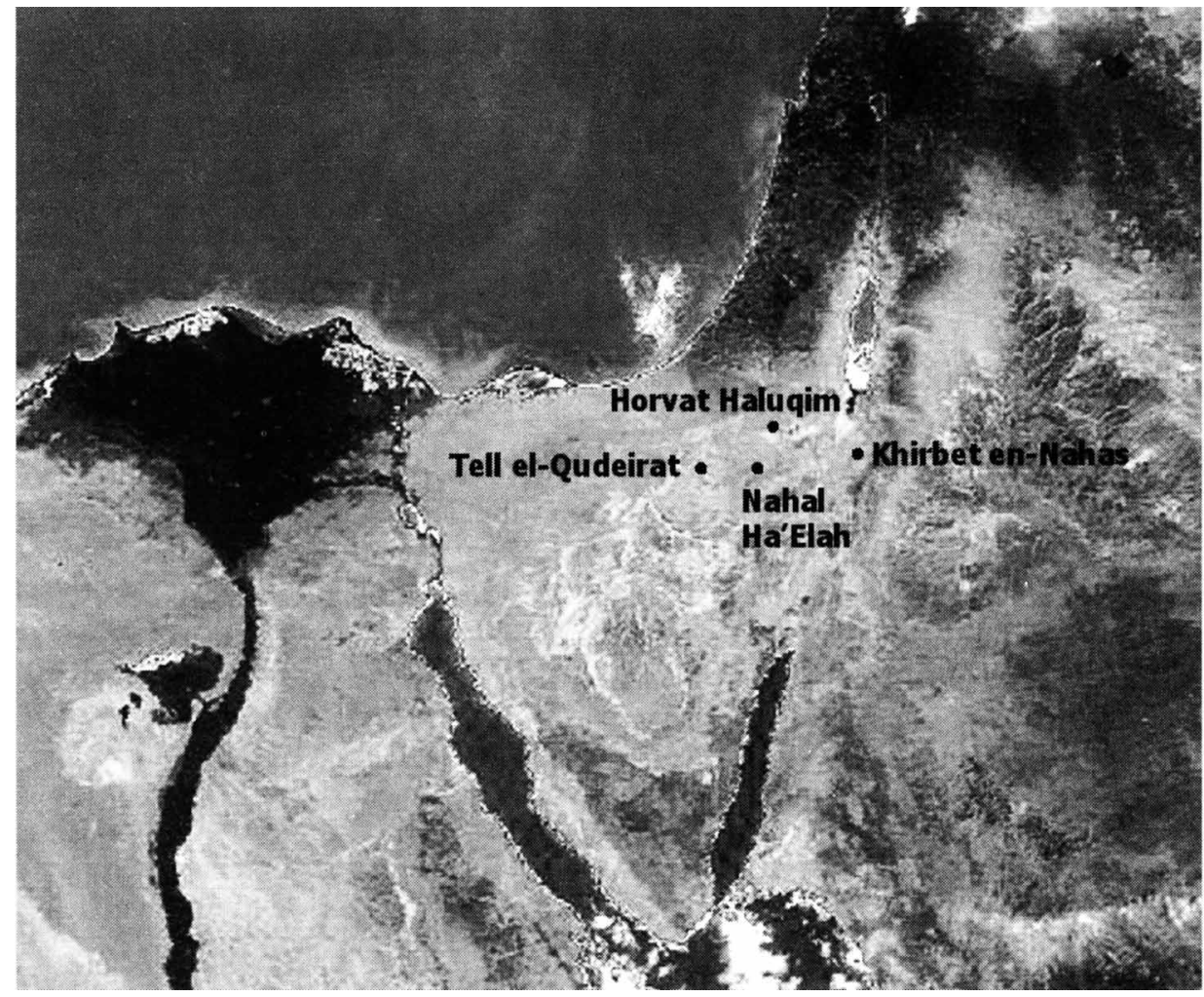

Figure 2 Regional map of the southern Levant based on a satellite image of 6 April 1998, showing the location of the principal sites mentioned in the text (after Bruins and van der Plicht 2005).

The terms Sinai and Negev in biblical texts relate in both cases to much smaller geographic areas in comparison to their modern meaning. The location of the biblical Negev is generally placed in the present northern Negev south of the Judean hills (Rainey 1978; Aharoni 1979, 1982; Herzog 1983; Kallai 1986). Various texts indicate that the Wilderness of Zin was situated roughly south of the biblical Negev, though the precise location is difficult to establish. Modern geographic names in Israel, derived from biblical Zin, are Nahal Zin (nahal in Hebrew is the equivalent of wadi in Arabic, i.e. a dry river valley occasionally flowing with water during a rainstorm), descending in the Zin Canyon and continuing northeastwards to the Dead Sea. The Arabic names of the 3 sections of Nahal Zin can be seen in Figure 1, the map by Woolley and Lawrence (1914-1915): Wadi Ramliya, Wadi Murra, and Wadi Figra, going from southwest along Abda (Avdat) to the northeast. It is noteworthy that the Bedouin used different names for the upper, middle, and lower part of this large wadi, but none seems related to the word Zin.

The biblical location of Kadesh-Barnea was apparently at the outer (southern, southeastern, or southwestern) edge of the Wilderness of Zin. An example can be found in Numbers 34:3-5:

Thus your south side shall be from the wilderness of Zin close by the side of Edom, and your south border shall begin at the end of the Salt Sea eastward; and your border shall turn about southward of the ascent of Akrabbim, and pass along to Zin; and the goings out thereof shall be southward of Kadesh-barnea; and it shall go forth to Hazar-addar, and pass along to Azmon; and the border shall turn about from Azmon unto the Brook of Egypt, and the goings out thereof shall be at the Sea (Jewish Publication Society of America 1917). 
A southeastern location of Kadesh-Barnea near the Arabah Valley was given by Josephus Flavius (1st century CE) and Eusebius (4th century CE). The traditional burial site of Aaron near Petra relates with such a southeasterly location. Explorers in the 19th century initially followed these early traditions and focused on springs in the Arabah Valley for the possible location of Kadesh-Barnea (Von Raumer 1831; Robinson and Smith 1841).

A southwestern location for Kadesh-Barnea in the Ain Kadeis area, in modern northeastern Sinai, was put forward by Rowlands (1845), Palmer (1871), and Trumbull (1884). Ain Kadeis was visited by Woolley and Lawrence during their survey, and they dismissed the small spring as a possible candidate. They found the amount of water only to be sufficient for a few families and their flocks. The apparent linguistic link between Kadeis and Kadesh was also contested by Woolley and Lawrence, who spoke Arabic well: "Kadeis, in Hejazi Arabic, is a scoop or bailer used in the bath for purification. The Sinai Arabs use such scoops (of wood) to lift up water from a shallow well. It does not mean 'holy', as Trumbull and other writers have assumed" (Woolley and Lawrence 1914-1915:53). Nevertheless, they were very much impressed by the nearby Ain el Qudeirat Valley (Figures 1, 2, and 3), with its copious spring, its lush valley along a stream of water, and the impressive remains of an ancient fortress. Woolley and Lawrence discussed the "vexed question of Kadesh-Barnea" and the options for its possible location, which "would most temptingly apply to the fortress of Ain Guderat, should we assume-we cannot prove it - that the fort was already built when Moses came" (Woolley and Lawrence 1914-1915:69-71).

Thus, the British explorers made it clear that they favored a possible association between the Ain el Qudeirat area and biblical Kadesh-Barnea. However, their suggested geographical correlation was linked to a conditional temporal relationship. The mention of Israel on the Merneptah Stele would seem to require a date at some time in the 2 nd millennium BCE, prior to $1200 \mathrm{BCE}$. Future excavations would have to answer the question about the age of the fortress at the tell near the spring of Ain el Qudeirat.

\section{THE MISSING 2ND MILLENNIUM IN NORTHEASTERN SINAI AND THE NEGEV HIGHLANDS ACCORDING TO ARCHAEOLOGICAL DATING}

Following the initial archaeological inspections of Tell el Qudeirat by Woolley and Lawrence in 1914, the first serious excavations were carried out in 1956 by Dothan (1965). The oldest wheelmade pottery found by Dothan in the limited area excavated was dated by him to the 9th century BCE. Large-scale excavations at the site were conducted by Cohen (1981a, 1993a) between 1976 and 1982. Cohen discovered that the tell was composed of 3 Iron Age fortresses from different time periods, superimposed on each other. The oldest, the Lower Fortress, which was oval in shape and smaller than the rectangular Middle and Upper fortresses, was dated by Cohen on archaeological criteria to the 10th century BCE and attributed to the period of King Solomon.

Therefore, Cohen seemed to have proven what Woolley and Lawrence were unable to accomplish during the few days they visited the site in 1914 - that Tell el Qudeirat cannot be associated with biblical Kadesh-Barnea because it is not old enough. Hence, Cohen took up the implications of his findings and published an article entitled "Did I excavate Kadesh-Barnea?" (Cohen 1981b). The matter is even more puzzling, as no archaeological finds of the 2nd millennium BCE were identified by Cohen and other archaeologists in the region of northeastern Sinai and the central Negev (Cohen 1980, 1981a,b,c, 1986, 1993a,b, 1999; Haiman 1986, 1991, 1993, 1994, 1996, 1999, 2003; Avni 1992; Rosen 1994; Cohen and Cohen-Amin 2004). 
Stone settlements did exist in this region from 2300-2000 BCE during the Intermediate Bronze Age (Dever 1973; Gophna 1992), also termed the Early Bronze IV (Dever 1998) or Middle Bronze I Age (Cohen 1983, 1993b). Approximately 1000 Middle Bronze (MB) I or Early Bronze (EB) IV settlements were found in the region (Haiman 1996), some of them quite large, such as Horvat Ein Ziq, composed of about 200 circular structures in an area of 5 acres (Cohen 1993b). No sites were discovered in the entire region dating to the subsequent period of 2000-1000 BCE, according to Cohen (1993b:1126): "After a gap of about a thousand years, habitation in the Negev Hills was renewed in the Iron Age II, with a change in the pattern of settlement." The empty 2nd millennium $\mathrm{BCE}$ in the region is a problem for the question of Kadesh-Barnea, as the early history of biblical Israel requires a temporal relationship with this time period (Malamat 2001). An alternative was suggested by Cohen (1983), who proposed that the older Middle Bronze I sites ( 2300-2000 BCE) may perhaps be related to biblical place names in the deserts of the southern Levant.

\section{ND MILLENNIUM ${ }^{14} \mathrm{C}$ DATES FROM NORTHEASTERN SINAI AND THE NEGEV HIGHLANDS}

Hendrik Bruins conducted research in the Ain el Qudeirat area during the early 1980s, working as a geoarchaeologist with the team headed by Rudolph Cohen. The initial focal points of the geoarchaeological aspects of the excavations were on the environment, to investigate landscape history in relation to Tell el Qudeirat (Figure 3) and other archaeological structures in the valley of Ain el Qudeirat (Bruins 1986). It became clear from the beginning of this research that ${ }^{14} \mathrm{C}$ dating should be the principal chronological method applied, being the only dating method that can link archaeological structures and layers to landscape strata, because the latter usually lacked ceramic inclusions but did contain charred organic remains. Cohen agreed that a few organic samples could be taken from the tell for ${ }^{14} \mathrm{C}$ dating, both for comparison and out of curiosity, as ceramic archaeological dating was considered far superior in the 1980s in comparison to ${ }^{14} \mathrm{C}$ dating (Weinstein 1984; Bruins 2001; van der Plicht and Bruins 2001).

The samples were submitted by Bruins to the Radiocarbon Laboratory of the Centre for Isotope Research at the University of Groningen (the Netherlands), and this formed the beginning of longstanding research cooperation, particularly focused on the historical archaeological periods in the southern Levant (Bruins and Mook 1989; van der Plicht and Bruins 2001).

\section{NEW INSIGHTS ON THE MISSING 2ND MILLENNIUM BCE}

The flow of time in the past has been the same in all fields of science, whether geology, climatology, archaeology, Egyptology, or Mesopotamian history. The problems we face are undoubtedly related to our limitations to reconstruct time accurately in relation to stratigraphic layers, material objects, or literary sources. Ceramic styles undeniably carry the mark of time, but how certain are we that current schemes for ceramic dating in the Bronze and Iron ages are correct? An example is the hotly debated problem of the High and Low Chronology in the Levantine Iron Age (cf. Finkelstein 2005; Levy and Higham 2005; Mazar 2005), as a certain complex of ceramics was understood by scholars to date either to the 10th or the 9th century BCE. This problem was investigated in great detail by ${ }^{14} \mathrm{C}$ dating at Tel Rehov, which showed that the ceramic complex in question dates to both the 10th and 9th century BCE (Bruins et al. 2003a; Mazar et al. 2005). Hence, ${ }^{14} \mathrm{C}$ dating may sometimes be capable to expose circular reasoning in ceramic dating, while crafting an independent contribution on its own merits (Bruins 2001; van der Plicht and Bruins 2001).

The following sections describe the context of ${ }^{14} \mathrm{C}$ dates that carry the time-mark of the missing 2nd millennium BCE from a number of archaeological sites in northeastern Sinai and the central Negev. The sites included are Tell el Qudeirat (Woolley and Lawrence 1914-15; Dothan 1965; Cohen 
1981a, 1993a) and nearby aqueduct remnants from the Valley of Ein el Qudeirat (Porath 1989), both in northeastern Sinai, as well as the Nahal Ha'Elah Fortress (Cohen 1986, 1993b) and agricultural terraces at Horvat Haluqim (Bruins and van der Plicht 2004, 2005) in the central Negev. A snapshot of those sites and the ${ }^{14} \mathrm{C}$ dates relevant to this paper are presented.

\section{Tell el Qudeirat}

An important sample was taken at Tell el Qudeirat in Square K-67, collected by Cohen and Bruins together from the lowermost ash layer at the tell, about $5 \mathrm{~m}$ below the tell surface and $20-30 \mathrm{~cm}$ above a natural gravel layer (Bruins 1986). This dark ash layer was associated by Cohen (1981a, 1993a) with the Lower Fortress, which he dated on archaeological grounds to the 10th century BCE (Iron Age IIA). However, the ${ }^{14} \mathrm{C}$ date of this ash layer $(\mathrm{GrN}-12330,2930 \pm 30 \mathrm{BP})$, which contained fine powdery charred organic matter, yielded a ${ }^{14} \mathrm{C}$ date that can be associated on the basis of time with Iron Age I. The calibrated date with the highest relative probability is 1195-1139 (32.1\%) within the $1-\sigma$ range, while the full $2-\sigma$ age range $(95.4 \%)$ is $1258-1022 \mathrm{BCE}$, using the OxCal program v 3.10 (Bronk Ramsey 1995, 2001) and the IntCal04 calibration curve (Reimer et al. 2004). These ${ }^{14} \mathrm{C}$ dating results are comparable to chronological suggestions made by Rothenberg ( 1972 . 1988, 1999) and Finkelstein (1988) for settlement in the Negev area. Similar ${ }^{14} \mathrm{C}$ dates from stratified excavations at the Iron Age metal production site of Khirbat en-Nahas, in nearby southwestern Jordan on the edge of the Arabah Valley, were obtained by Levy et al. $(2004,2005)$ and Higham et al. (2005). Other ${ }^{14} \mathrm{C}$ dates from Tell el Qudeirat yielded dates consistent with the archaeological stratigraphy in relation to the Middle Fortress and Upper Fortress (Bruins and van der Plicht 2005).

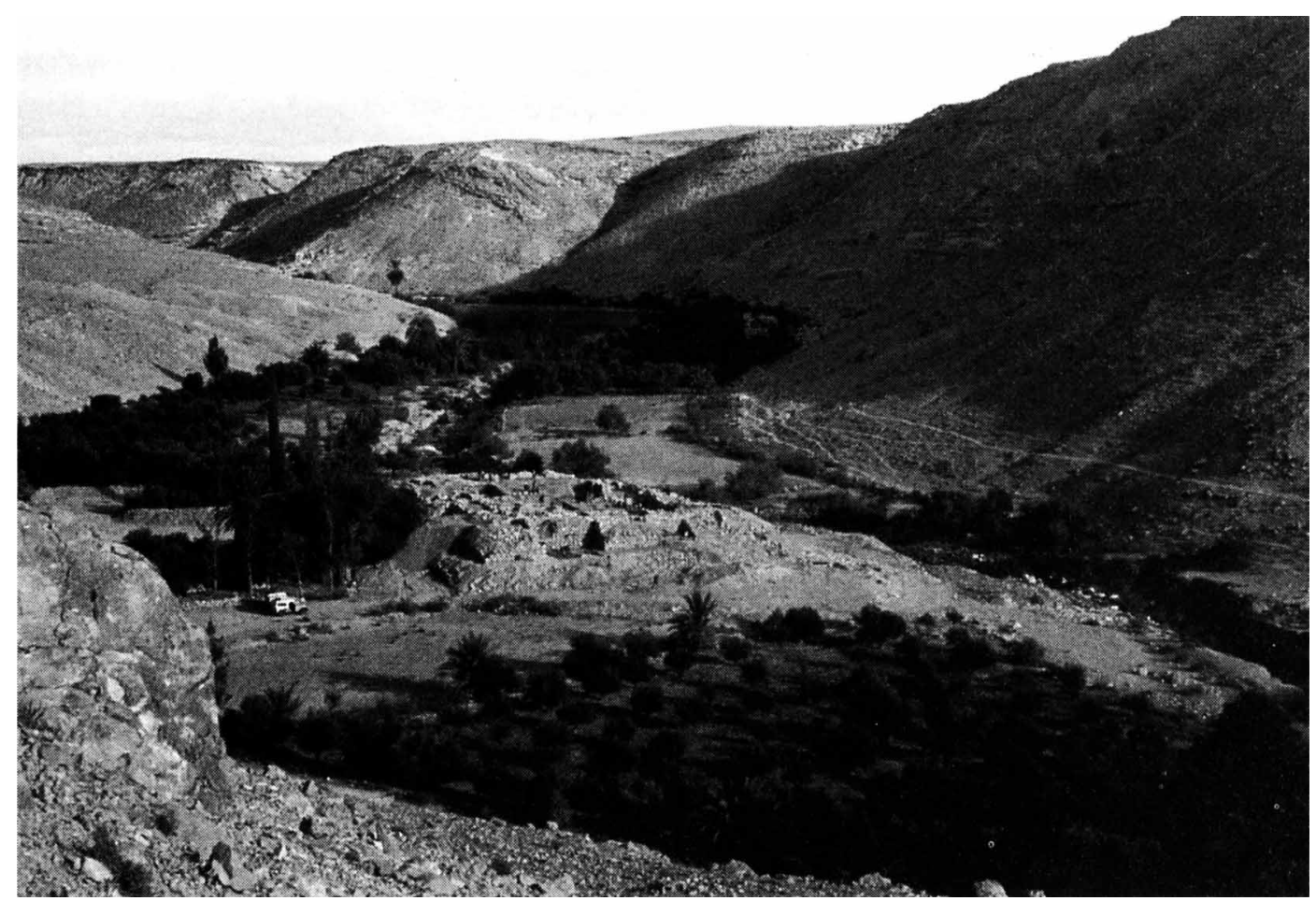

Figure 3 The valley of Ain el Qudeirat with the tell in the center of the picture (photograph by HJ Bruins. 20 December 1981) 


\section{Ain el Qudeirat Valley}

The valley of Ain el Qudeirat contains remnants of various aqueduct systems (Porath 1989). The aqueducts were lined with stones and lime mortar. Small pieces of charcoal usually appear throughout the mortar, which facilitated ${ }^{14} \mathrm{C}$ dating of the aqueducts. Remnants of a large dam in the valley of Ain el Qudeirat, which once blocked the valley, had an aqueduct system beginning on its top. ${ }^{14} \mathrm{C}$ dates of this dam-aqueduct and another aqueduct remnant further downstream both gave almost similar ${ }^{14} \mathrm{C}$ dates in the 7 th century CE (Bruins 1986). These dates would fit either the end of the Byzantine period or the beginning of the Early Muslim period. A third aqueduct remnant about $400 \mathrm{~m}$ downstream from the actual spring of Ain el Qudeirat, also lined with stones and lime mortar containing fine charcoal pieces, gave a ${ }^{14} \mathrm{C}$ date in the middle of the 2 nd millennium $\mathrm{BCE}(\mathrm{GrN}$ $12327,3270 \pm 100 \mathrm{BP})$. The amount of charcoal was not sufficient for a more precise date with the GPC system; the AMS system was not yet available during the time of measurement in the 1980s (van der Plicht et al. 2000). The calibrated age with the highest relative probability is 1641-1438 BCE (64.9\%), which could fit either the Middle Bronze Age II or the Late Bronze Age, in materialcultural terms.

\section{Nahal Ha'Elah Fortress}

The site lies in the central Negev about $10 \mathrm{~km}$ north of the Makhtesh Ramon cirque (Bruins and van der Plicht 2005), somewhat northeast of the number 2975 (feet, altitude) on the map (Figure 1) by Woolley and Lawrence (1914-1915). The fortress is located on a hill $(685 \mathrm{~m})$, about $1 \mathrm{~km}$ south of an Iron Age settlement (Cohen 1986). The fortress was excavated in 1983 by Cohen $(1986,1993 b)$. It has an elliptical shape $(34 \times 20 \mathrm{~m})$ and consists of 13 casemate rooms and a gate surrounding a central courtyard. The excavated casemate rooms often showed a thin ash layer, and a larger charcoal sample from one of the rooms was given by Cohen for ${ }^{14} \mathrm{C}$ dating. Both the building of the fortress and its destruction were dated by Cohen to the 10th century BCE $(1986,1993 \mathrm{~b})$, as well as most other Iron Age fortresses in the central Negev (Haiman 1994, 2003). The large charcoal sample was suited for high-precision measurement with GPC and gave a date of $2840 \pm 15 \mathrm{BP}$ (GrN$15552)$. The $1-\sigma$ calibrated age is $1016-973(54.4 \%), 955-940(13.8 \%) \mathrm{BCE}$, and the 2- $\sigma$ calibrated age is $1048-968(73.0 \%), 962-928(22.4 \%)$ BCE. The most probable part of the 2- $\sigma$ date covers the last half of the 11 th century and the first decades of the 10th century BCE. However, as woody charcoal formed part of the sample, an old-wood effect cannot be excluded.

\section{Horvat Haluqim}

The Iron Age site of Horvat Haluqim is situated in the central Negev about $12 \mathrm{~km}$ northeast of Abda (Avdat) (Figure 1). The site comprises an oval fortress $(21 \times 23 \mathrm{~m})$, seven 4-room houses, other buildings, and 4 cisterns (Cohen 1976) situated along 3 parallel dry stream valleys (wadis) with terraced fields at the southeastern slopes of the Haluqim Anticline (Bruins 1986; Bruins and van der Plicht 2004, 2005). The geographic view from the site southeastwards includes the outlines of the Zin Canyon, which constitutes the most convenient east-west connection with the Arabah and sites such as Khirbet en-Nahas (Levy et al. 2005) in southwestern Jordan (Figures 1, 2). Most buildings at the site were excavated by Cohen $(1976,1980,1993 \mathrm{~b})$, who classified them as Iron Age IIA and assigned them to the 10th century BCE, making a suggested linkage with the period of King Solomon.

Bruins has carried out surveys and geoarchaeological excavations in the 3 terraced wadis of Horvat Haluqim and found distinct evidence for past soil manuring and use of runoff agriculture during the Iron Age (Bruins 1986; Bruins and van der Plicht 2004). Excavations in 2004 in a new area (Area 5) 
of Terrace 12 in the eastern wadi of Horvat Haluqim gave a remarkable stratigraphic profile of the anthropogenic soil (Figure 4). Microscopic studies of thin sections from various parts of this soil in different areas of Terrace 12 showed that small pieces of charred organic matter are mixed throughout the soil, accompanied by occasional pieces of animal bone (goat or sheep; Table 1). This is evidently the result of purposeful manuring of the soil with kitchen refuse, i.e. charred organic ash and food remnants-bones (Bruins 1986; Bruins and van der Plicht 2004, 2005). Some pottery sherds and worked flint also appear occasionally in the anthropogenic soil, perhaps dumped with the kitchen refuse (Wilkinson 2003). These cultural remains are usually non-diagnostic, but some were identified as Iron Age sherds and Negbite ware, to be published later. Very large amounts of spherulites in the anthropogenic soil, as compared with the present surface soil, strongly suggest past manuring also with animal dung, which, unlike charred organic remains, decomposes in the course of time leaving only the spherulites behind. A detailed paper about the micromorphology and contents of the anthropogenic soil at Horvat Haluqim is in preparation.

The stratigraphic profile in Area 5 of the anthropogenic soil yielded a number of spots with larger concentrations of this charred organic matter that could be sampled for ${ }^{14} \mathrm{C}$ dating. Five samples gave dates that are mainly situated in the 2 nd millennium BCE (Table 1), covering a total time range of about 1550-950 BCE. Three dates derived from the base of the anthropogenic terrace soil are even older! Their ages and ramifications will be published elsewhere, indicating that runoff agriculture and the application of organic fertilizers to the soil of agricultural terraced wadi fields in the central Negev Desert began unexpectedly early in time.

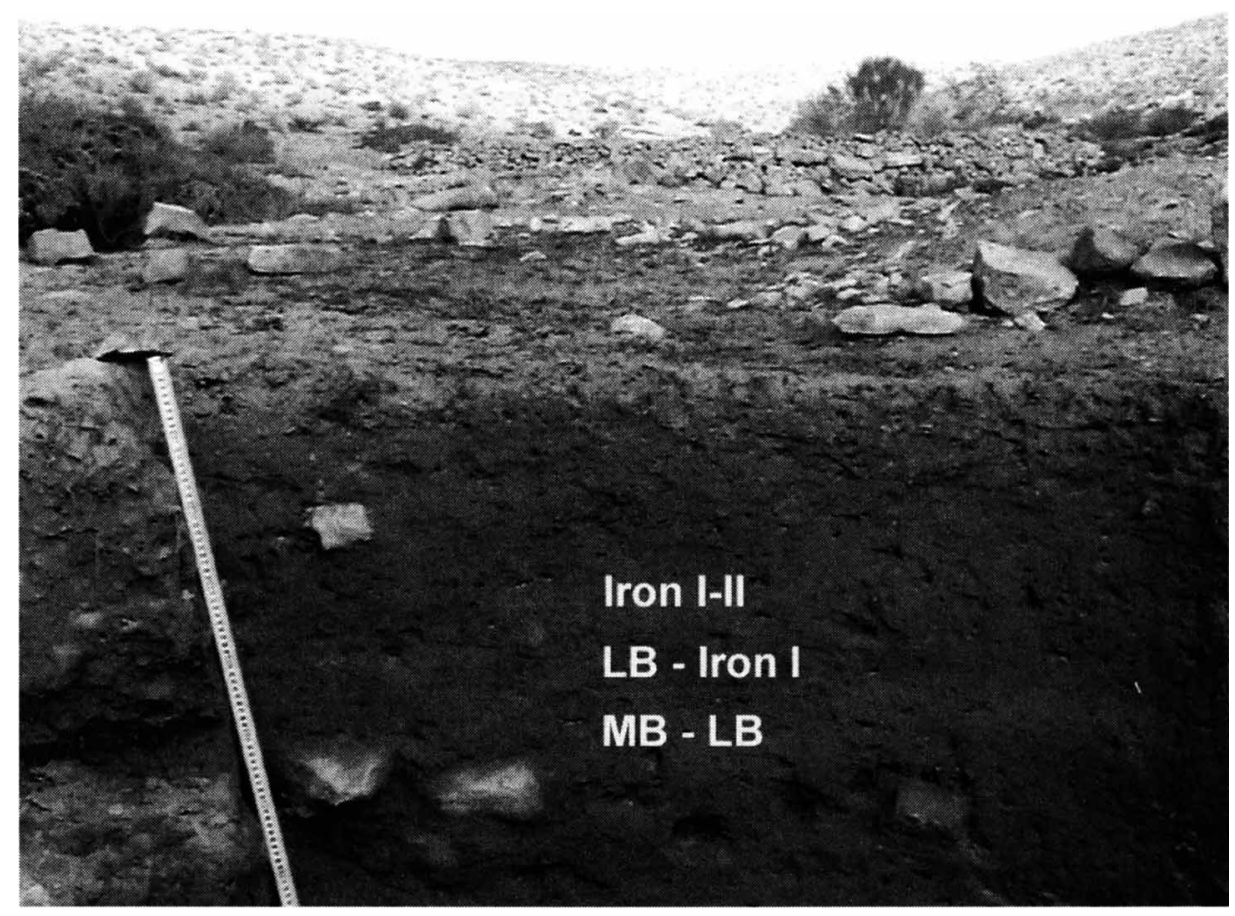

Figure 4 Terraced field 12 in the eastern wadi of Horvat Haluqim, Area 5, showing the anthropogenic soil and the ${ }^{14} \mathrm{C}$-dated layers in terms of archaeological periods, associated on the basis of time. 


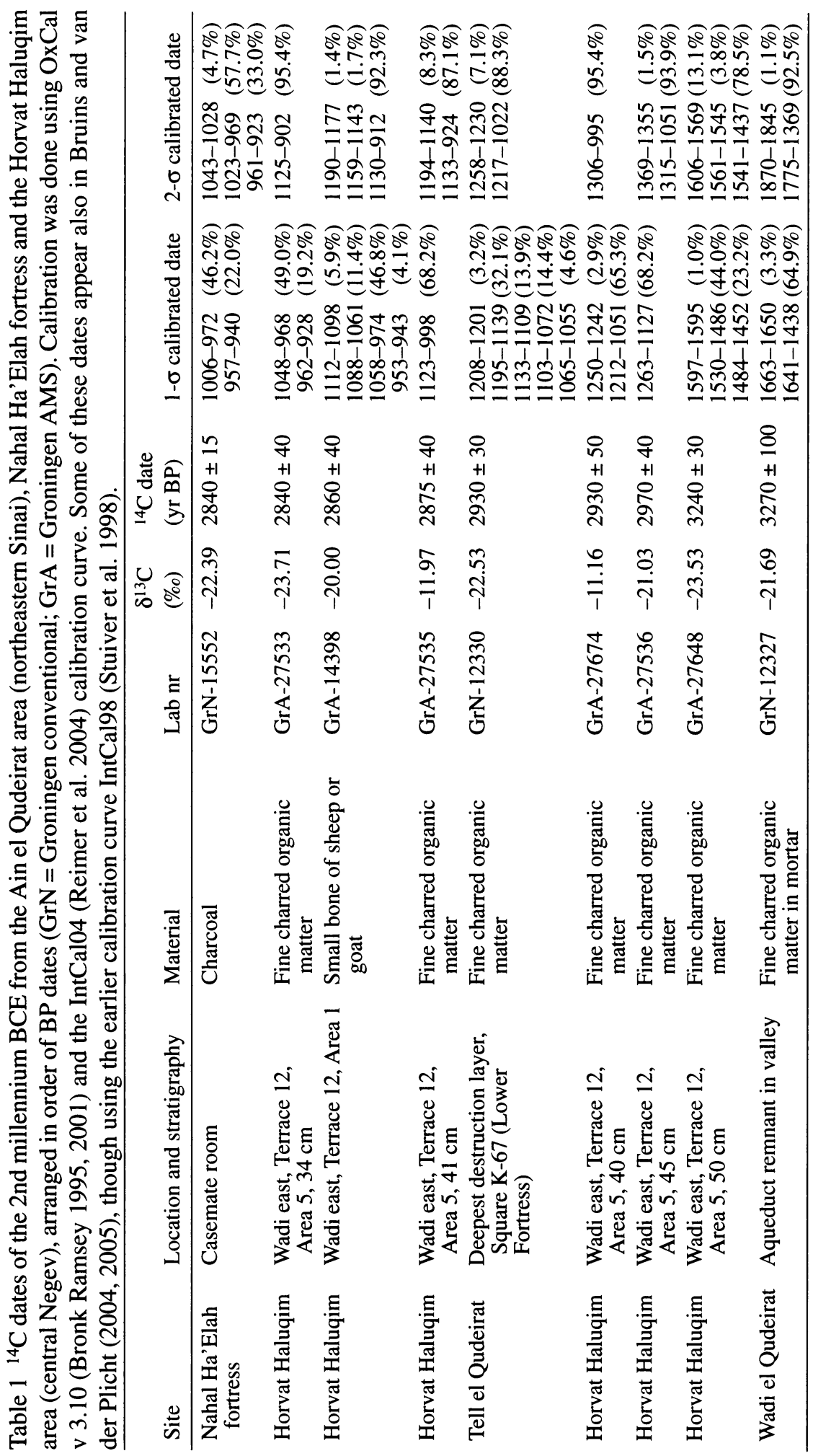


Concerning the 2 nd millennium $\mathrm{BCE}$, the ${ }^{14} \mathrm{C}$ dating results-which are consistent in relation to the soil stratigraphy-show that people lived in the central Negev area in the Middle Bronze/Late Bronze Age and Iron Age I, and practiced runoff farming. We do not know yet where they lived and in what type of structures, but the anthropogenic soil evidence in itself is robust. Systematic mixing of the surface soil with charred organic matter (ash) and pieces of animal bones over the entire width of the terraced field cannot be accomplished by natural processes, but only by purposeful human activities to improve the soil fertility. Though the oldest stone houses at Horvat Haluqim were interpreted to belong only to the 10th century BCE in Iron Age II (Cohen 1976), the anthropogenic soil in Terrace 12 of the eastern wadi contains unmistakable evidence that people were using the area in the 2nd millennium BCE.

The current height of the check dam was apparently reached gradually throughout different archaeological periods. The top of the dam has to remain above the soil surface to arrest the flow of runoff water and to cause increased infiltration of water into the soil. New sediment continued to accumulate with each runoff flow, and the soil surface in the terraced field became higher and higher. Hence, people had to increase the height of the check dam gradually during the various periods they used the terraced field. People also continued to apply charred organic matter to the soil surface, as witnessed by the content of the anthropogenic soil, which is more than $1 \mathrm{~m}$ in thickness. This accumulating soil recorded human activities through time.

The terraced field was also used during the period $\sim 1550-950 \mathrm{BCE}$, based on $6{ }^{14} \mathrm{C}$ dates. People may have lived in tents, like the Bedouin do in the area in modern times, using the landscape for grazing and runoff farming. However, it is interesting to note that Bedouin nowadays do not use ash from fires to improve soil fertility and hardly ever use manure at all, according to personal observations and conversations with Bedouin in the region. The ${ }^{14} \mathrm{C}$ results do not imply that people lived here for the above time period without interruption. But the terraced field remained even after abandonment, and later in time new groups of people would notice and reuse it.

Thus, human-made anthropogenic soils in terraced wadis in the central Negev recorded unique data of land use in the past in an accumulative sedimentological environment, which can neither be seen nor deciphered in a conventional archaeological approach (which focuses on stone building remains, stone implements, and pottery concentrations). Studying the record of terraced soils in wadis requires the tools of geoarchaeology and ${ }^{14} \mathrm{C}$ dating (Bruins 2005).

\section{DISCUSSION AND CONCLUSIONS}

Modern archaeological excavations and surveys in the northeastern Sinai and central Negev deserts did not identify any remains belonging to the 2 nd millennium BCE. This period is critical in relation to the early history and emergence of Israel. The suggested association of the area of Ain Kadeis and/or Ain el Qudeirat in northeastern Sinai with biblical Kadesh-Barnea, proposed by travelers and scholars in the second half of the 19th century, and by Woolley and Lawrence in 1914, did not pass the test of conventional archaeology, as no remains of the 2nd millennium BCE (Iron Age I, Late Bronze, and Middle Bronze Age II) were found or identified in the area.

However, ${ }^{14} \mathrm{C}$ dating of organic material retrieved during excavations carried out at key sites in the "Wilderness of Zin" and geoarchaeological investigations did yield data belonging to the 2nd millennium BCE. Many past activities of human beings, such as walking, traveling, herding, farming, and living in tents do not necessarily leave comprehensible traces behind in terms of material culture. However, a ${ }^{14} \mathrm{C}$ date in an anthropogenic deposit or agricultural soil is as hard a piece of evidence as a diagnostic pottery sherd-perhaps even harder, as the age of a Negbite sherd is hard to decipher. Quaternary geological research and prehistoric archaeology have long used ${ }^{14} \mathrm{C}$ dating for 
chronology. Does a ${ }^{14} \mathrm{C}$ date suddenly change its validity in the Iron Age and Bronze Age? Indeed, cultural terms and their subphases may be highly problematic in terms of real time. Paraphrasing Braidwood (1946), from prehistory into historical archaeology, one might say:- to assume that we have "dated" a certain fortress or layer by calling it simply "Iron-Age II" is meaningless, as the latter is not a term with primarily chronological meaning (Bruins and Mook 1989:1019).

Our research showed that the deepest ash layer at Tell el Qudeirat, related by Cohen to the Lower Fortress, would compare in terms of time with the cultural period termed Iron Age I in the region of the southern Levant, as the most probable calibrated age range is 1195-1139 BCE (GrN-12330), though some archaeologists would prefer to have the first half of the 12th century included in the Late Bronze Age (see Ben-Tor 1992). The type of charred organic matter from the above layer seems derived from short-lived shrubs or grasses, as chunks of woody charcoal were not noticed. A possible old-wood effect seems negligible.

There are a number of aqueduct remnants in the valley of Ain el Qudeirat. Such remnants are problematic in terms of conventional archaeological dating, as a connection with diagnostic ceramics cannot usually be established. We dated 3 different aqueduct remnants on fine charred organic matter found inside the mortar lining. Two aqueduct remnants dated to the 7 th century $C E$ and 1 to the 2nd millennium BCE, the most probable age being 1641-1438 BCE. The old-wood loophole can be employed to nullify this date, but why this aqueduct remnant and not the 2 other aqueducts that dated to the 7th century CE (Late Byzantine-Early Muslim times)? Another objection seems that no MB/LB settlements were identified in the area and an aqueduct without a settlement seems a problem. Indeed, more dates of this aqueduct remnant for verification would be highly desirable, but unfortunately more material cannot currently be obtained from northeastern Sinai. This is what we have and it should be reported.

The fortress at Nahal Ha'Elah has a similar oval shape as the Lower Fortress at Tell el Qudeirat and the fortress at Horvat Haluqim. All were dated to the 10th century BCE by Cohen (1980). The ${ }^{14} \mathrm{C}$ date for the destruction layer in one of the casemate rooms of the Nahal Ha'Elah fortress is ambiguous, as both the 11 th century and 10th century are possible. If the above date relates to its destruction, the question remains as to when this fortress and the other oval fortresses in the region were built for the first time. The geographical relationships and ages of sites in nearby southwestern Jordan (Edom) in the Arabah Valley and beyond are also very important in this respect (Bienkowski 1995; Bienkowski and Galor 2006). The ${ }^{14} \mathrm{C}$ dates of Khirbat en-Nahas and their ramifications are particularly significant (Levy et al. 2004, 2005; Finkelstein 2005b; Higham et al. 2005; Levy and Najjar 2006a,b), as the 12th and 11th centuries BCE are also represented, like some of our dates in northeastern Sinai and at Horvat Haluqim in the central Negev.

The excavated terraced field in the eastern Wadi of Horvat Haluqim, the same wadi that flows along the oval fortress $170 \mathrm{~m}$ downstream, has yielded by now $6{ }^{14} \mathrm{C}$ dates within the 2 nd millennium $\mathrm{BCE}$ covering a total time range of about 1550-950 BCE. One date in the Middle to Late Bronze Age range (GrA-27648) is similar to the date for the above aqueduct remnant (GrN-12327) in the Ain el Qudeirat Valley (Table 1). Most other dates in Area 5 favor the Early Iron Age or Late Bronze Age rather than Iron Age II, in temporal terms.

In contrast with most archaeological assessments thus far, our investigations based on ${ }^{14} \mathrm{C}$ dating show that the "Wilderness of Zin" region of northeastern Sinai and the central Negev is not devoid of archaeological remains from the 2nd millennium BCE. A significant part of this region constitutes an ecological niche due to comparatively higher elevation, good soils in wadis with a landscape geomorphology naturally suited for rainwater harvesting (runoff) agriculture, as well as some 
springs. It would seem irrational that people did not enter and use these regions for such a long period of $1 \mathrm{kyr}$, from 2000 to $1000 \mathrm{BCE}$.

\section{ACKNOWLEDGMENTS}

Dr Rudolph Cohen was for many years the driving force in most archaeological research of the central Negev region and northeastern Sinai during the 1970s and 1980s. We acknowledge the large scope and importance of his work. We thank him, his staff, and the Israel Antiquities Authority for their cooperation in the sampling and provision of the organic material for ${ }^{14} \mathrm{C}$ dating, and the permit for the geoarchaeological excavations at Horvat Haluqim. We are thankful to the technical staff of the Centre for Isotope Research (University of Groningen) for the ${ }^{14} \mathrm{C}$ measurements. The comments by the 2 reviewers considerably improved the final text and are gratefully acknowledged.

\section{REFERENCES}

Aharoni Y. 1979. The Land of the Bible: A Historical Geography. [Rainey AF, translator]. Philadelphia: The Westminster Press. 409 p.

Aharoni Y. 1982. The Archaeology of the Land of Israel: From the Prehistoric Beginnings to the End of the First Temple Period. [Rainey AF, translator]. Philadelphia: The Westminster Press. 344 p.

Avni G. 1992. Archaeological Survey of Israel: Map of Har Saggi-Northeast (225). Jerusalem: The Israel Antiquities Authority and the Archaeological Survey of Israel.

Bienkowski P. 1995. The Edomites: the archaeological evidence from Transjordan. In: Edelman DV, editor. You Shall Not Abhor an Edomite for He is Your Brother: Edom and Seir in History and Tradition. Archaeological and Biblical Studies 3. Atlanta: American Scholars Press. p 41-92.

Bienkowski P, Galor K, editors. 2006. Crossing the Rift: Resources, Routes, Settlement Patterns and Interaction in the Wadi Arabah. Levant Supplementary Series 3. Oxford: Oxbow Books. 288 p.

Ben-Tor A. 1992. Introduction. In: Ben-Tor A, editor. The Archaeology of Ancient Israel. New Haven: Yale University Press. p 1-9.

Boaretto E, Jull AJT, Gilboa A, Sharon I. 2005. Dating the Iron Age I/II transition in Israel: first intercomparison results. Radiocarbon 47(1):39-55.

Braidwood RJ. 1946. Terminology in Prehistory, Human Origins, an Introductory General Course in Anthropology, Selected Reading Series II. Chicago: University of Chicago Press. p 32-45.

Bronk Ramsey C. 1995. Radiocarbon calibration and analysis of stratigraphy: the OxCal program. Radiocarbon 37(2):425-30.

Bronk Ramsey C. 2001. Development of the radiocarbon program. Radiocarbon 43(2A):355-63.

Bruins HJ. 1986. Desert environment and agriculture in the central Negev and Kadesh-Barnea during historical times [PhD dissertation]. Wageningen: University of Wageningen; Nijkerk: Stichting Midbar Foundation.

Bruins HJ. 2001. Near East chronology: towards an inte- grated ${ }^{14} \mathrm{C}$ time foundation. Radiocarbon $43(3)$ : 1147 54.

Bruins HJ. 2005. Ancient agriculture in the Negev: the soil as an archaeological and environmental archive. In: Ackermann O, Faust A, Maeir A, editors. Archaeology and Environment. Ramat Gan: The Martin (Szusz) Department of Land of Israel Studies and Archaeology, Bar-Ilan University. p 171-7. In Hebrew.

Bruins HJ, Berliner PR. 1998. Bioclimatic aridity, climatic variability, drought and desertification. In: Bruins HJ, Lithwick H, editors. The Arid Frontier: Interactive Management of Environment and Development. Dordrecht: Kluwer Academic. p 97-116.

Bruins HJ, Mook WG. 1989. The need for a calibrated radiocarbon chronology of Near Eastern archaeology. Radiocarbon 31(3):1019-29.

Bruins HJ, van der Plicht J. 2004. Desert settlement in the central Negev: first ${ }^{14} \mathrm{C}$ indication of rainwater-harvesting agriculture in the Iron Age. In: Higham TFG, Bronk Ramsey C, Owen DC, editors. Radiocarbon and Archaeology: Proceedings of the 4th International Symposium, Oxford, 2002. Oxford: Oxford University School of Archaeology Monograph 62. p 8398.

Bruins HJ, van der Plicht J. 2005. Desert settlement through the Iron Age: radiocarbon dates from Sinai and the Negev highlands. In: Levy TE, Higham T, editors. The Bible and Radiocarbon Dating: Archaeology, Text and Science. London: Equinox. p 349-66.

Bruins HJ, van der Plicht J, Mazar A. 2003a. ${ }^{14} \mathrm{C}$ dates from Tel Rehov: Iron-Age chronology, pharaohs and Hebrew kings. Science 300(5617):315-8.

Bruins HJ, van der Plicht J, Mazar A. 2003b. Response to comment on " ${ }^{14} \mathrm{C}$ dates from Tel Rehov: Iron-Age chronology, pharaohs and Hebrew kings." Science 302(5645):568c.

Bruins HJ, van der Plicht J, Ilan D, Werker E. 2005a. Iron Age ${ }^{14} \mathrm{C}$ dates from Tel Dan-a High Chronology. In: Levy TE, Higham T, editors. The Bible and Radiocarbon Dating: Archaeology, Text and Science. London: Equinox. p 323-36. 
Bruins HJ, van der Plicht J, Mazar A, Bronk Ramsey C, Manning SW. 2005b. The Groningen radiocarbon series from Tel Rehov: OxCal Bayesian computations for the Iron IB-IIA boundary and Iron IIA destruction events. In: Levy TE, Higham T, editors. The Bible and Radiocarbon Dating: Archaeology, Text and Science. London: Equinox. p 271-93.

Cohen R. 1976. Excavations at Horvat Haluqim. Atiqot 11:34-50.

Cohen R. 1980. The Iron Age fortresses in the central Negev. Bulletin of the American Schools of Oriental Research 236:61-79.

Cohen R. 1981a. Excavations at Kadesh-barnea 19761978. Biblical Archeologist 44(2):93-107.

Cohen R. 1981b. Did I excavate Kadesh-Barnea? Biblical Archaeological Review 7(3):20-33.

Cohen R. 1981c. Archaeological Survey of Israel: Map of Sede Boqer-East (168). Jerusalem: The Archaeological Survey of Israel.

Cohen R. 1983. The mysterious MBI people: Does the Exodus tradition in the Bible preserve the memory of their entry into Canaan? Biblical Archaeological Review 9(4):16-29.

Cohen R. 1986. The settlement of the central Negev in the light of archaeology and literary sources during the 4th-1st millennia BCE [unpublished PhD dissertation]. Jerusalem: The Hebrew University of Jerusalem. In Hebrew.

Cohen R. 1993a. Kadesh-Barnea. The Israelite fortress. In: Avi-Yonah M, editor. The New Encyclopedia of Archaeological Excavations in the Holy Land. Volume 3. New York: Simon and Schuster. p 843-47.

Cohen R. 1993b. Middle Bronze Age I and Iron Age II sites in the Negev highlands. In: Avi-Yonah M, editor. The New Encyclopedia of Archaeological Excavations in the Holy Land. Volume 3. New York: Simon and Schuster. p 1123-33.

Cohen R. 1999. Ancient Settlement of the Central Negev. Volume I. The Chalcolithic Period, the Early Bronze Age and the Middle Bronze Age I. Jerusalem: The Israel Antiquities Authority, IAA Reports No. 6. 396 p. In Hebrew with English summary.

Cohen R, Cohen-Amin R. 2004. Ancient Settlement of the Central Negev. Volume II. The Iron Age and the Persian Period. Jerusalem: The Israel Antiquities Authority, IAA Reports No. 20. In Hebrew with English summary.

Dever WG. 1973. The EB IV-MB I horizon in Transjordan and southern Palestine. Bulletin of the American Schools of Oriental Research 210:37-63.

Dever WG. 1995. Ceramics, ethnicity, and the question of Israel's origins. The Biblical Archaeologist 58(4): 200-13.

Dever WG. 1998. Social structure in the Early Bronze IV period in Palestine. In: Levy TE, editor. The Archaeology of Society in the Holy Land. London: Leicester University Press. p 282-96.

Dothan M. 1965. The fortress at Kadesh Barnea. Israel
Exploration Journal 15:134-51.

Epstein I. 1960. Judaism. London: Penguin Books. $352 \mathrm{p}$.

Finkelstein I. 1988. Arabian trade and socio-political conditions in the Negev in the twelfth-eleventh centuries BCE. Journal of Near Eastern Studies 47(4):24152.

Finkelstein I. 2005a. A Low Chronology update-archaeology, history and bible. In: Levy TE, Higham T, editors. The Bible and Radiocarbon Dating: Archaeology, Text and Science. London: Equinox. p 31-42.

Finkelstein I. 2005b. Khirbet en-Nahas, Edom and biblical history. Tel Aviv 32(1):119-25.

Finkelstein I, Piasetzky E. 2003. Comment on ${ }^{~}{ }^{14} \mathrm{C}$ dates from Tel Rehov: Iron-Age chronology, pharaohs and Hebrew kings." Science 302(5645):568.

Gilboa A, Sharon I. 2001. Early Iron Age radiometric dates from Tel Dor: preliminary implications for Phoenicia and beyond. Radiocarbon 43(3):1343-51.

Gilboa A, Sharon I. 2003. An archaeological contribution to the Early Iron Age chronological debate: alternative chronologies for Phoenicia and their effects on the Levant, Cyprus, and Greece. Bulletin of the American Schools of Oriental Research 332:7-80.

Gophna R. 1992. The Intermediate Bronze Age. In: BenTor A, editor. The Archaeology of Ancient Israel. New Haven: Yale University Press. p 126-58.

Goren Y, Finkelstein I, Na'aman N. 2004. Inscribed in Clay: Provenance Study of the Amarna Letters and other Ancient Near Eastern Texts. Tel Aviv: Tel Aviv University Monograph Series 31.

Haiman M. 1986. Archaeological Survey of Israel: Map of Har Hamran-Southwest (198). Jerusalem: The Department of Antiquities and Museums and the Archaeological Survey of Israel.

Haiman M. 1991. Archaeological Survey of Israel: Map of Mizpe Ramon-Southwest (200). Jerusalem: The Israel Antiquities Authority and the Archaeological Survey of Israel.

Haiman M. 1993. Archaeological Survey of Israel: Map of Har Hamran-Southeast (199). Jerusalem: The Israel Antiquities Authority and the Archaeological Survey of Israel.

Haiman M. 1994. The Iron Age II sites of the western Negev Highlands in light of the Negev Emergency Survey 1979-1989. Israel Exploration Journal 44:36-61.

Haiman M. 1996. Early Bronze Age IV settlement pattern of the Negev and Sinai deserts: view from small marginal temporary sites. Bulletin of the American Schools of Oriental Research 303:1-32.

Haiman M. 1999. Archaeological Survey of Israel: Map of Har Ramon (203). Jerusalem: The Israel Antiquities Authority and the Archaeological Survey of Israel.

Haiman M. 2003. The 10th century B.C. settlement of the Negev Highlands and Iron Age rural Palestine. In: Maeir AM, Dar S, Safrai Z, editors. The Rural Landscape of Ancient Israel. Oxford: BAR International Series 1121. p 71-90. 
Hasel MG. 1994. Israel in the Merneptah Stela. Bulletin of the American Schools of Oriental Research 296:4561.

Herzog Z. 1983. Enclosed settlements in the Negeb and the Wilderness of Beer-sheba. Bulletin of the American Schools of Oriental Research 250:41-9.

Higham T, van der Plicht J, Bronk Ramsey C, Bruins HJ, Robinson M, Levy TE. 2005. Radiocarbon dating of the Khirbat-en Nahas site (Jordan) and Bayesian modeling of the results. In: Levy TE, Higham T, editors. The Bible and Radiocarbon Dating: Archaeology, Text and Science. London: Equinox. p 164-78.

Jewish Publication Society of America. 1917. The Holy Scriptures According to the Masoretic Text: A New Translation with the Aid of Previous Versions and with Constant Consultation of Jewish Authorities (1955 reprint of 1917 edition). Philadelphia: Jewish Publication Society of America. Online version: http:// www.mechon-mamre.org/index.htm.

Kallai Z. 1986. Historical Geography of the Bible: The Tribal Territories of Israel. Jerusalem: Magnes Press; Leiden: Brill Academic. 543 p.

Levy TE, Adams RB, Najjar M, Hauptmann A, Anderson JA, Brandl B, Robinson MA, Higham T. 2004. Reassessing the chronology of Biblical Edom: new excavations and ${ }^{14} \mathrm{C}$ dates from Khirbat en-Nahas (Jordan). Antiquity 78(302):865-79.

Levy TE, Higham T. 2005. Radiocarbon dating and the Iron Age of the southern Levant: problems and potentials for the Oxford Conference. In: Levy TE, Higham T, editors. The Bible and Radiocarbon Dating: Archaeology, Text and Science. London: Equinox. p 314.

Levy TE, Najjar M, van der Plicht J, Smith NG, Bruins HJ, Higham T. 2005. Lowland Edom and the High and Low chronologies: Edomite state formation, the bible and recent archaeological research in southern Jordan. In: Levy TE, Higham T, editors. The Bible and Radiocarbon Dating: Archaeology, Text and Science. London: Equinox. p 129-63.

Levy TE, Najjar M. 2006a. Edom and copper-the emergence of Ancient Israel's rival. Biblical Archaeology Review 32(4):24-35, 70.

Levy TE, Najjar M. 2006b. Some thoughts on Khirbet en-Nahas, Edom, biblical history and anthropologya response to Israel Finkelstein. Tel Aviv 33(1):3-17.

Malamat A. 2001. History of Biblical Israel: Major Problems and Minor Issues. Leiden: Brill Academic. $496 \mathrm{p}$.

Mazar A. 1993. Archaeology of the Land of the Bible: 10,000-586 B.C.E. Cambridge: Lutterworth Press. $608 \mathrm{p}$.

Mazar A. 2005. The debate over the chronology of the Iron Age in the southern Levant. In: Levy TE, Higham T, editors. The Bible and Radiocarbon Dating: Archaeology, Text and Science. London: Equinox. p 1542.
Mazar A, Bruins HJ, Panitz-Cohen N, van der Plicht J. 2005. Ladder of time at Tel Rehov: stratigraphy, archaeological context, pottery and radiocarbon dates. In: Levy TE, Higham T, editors. The Bible and Radiocarbon Dating: Archaeology, Text and Science. London: Equinox. p 193-255.

Moran WL. 1992. The Amarna Letters. Baltimore: Johns Hopkins University Press. 448 p.

Palmer EH. 1871. The Desert of the Exodus: Journeys on Foot in the Wilderness of the Forty Years' Wanderings. Cambridge: Deighton, Bell and Company. $490 \mathrm{p}$.

Porath Y. 1989. Ancient agriculture at Kadesh Barnea Oasis. In: Amit D, Hirschfeld Y, Patrich J, editors. The Aqueducts of Ancient Palestine. Jerusalem: Yad Itzhak Ben-Zvi. p 325-35. In Hebrew.

Rainey AF. 1978. The toponymics of Eretz-Israel. Bulletin of the American Schools of Oriental Research 231: $1-17$.

Redford DB. 1992. Egypt, Canaan and Israel in Ancient Times. Princeton: Princeton University Press. 512 p.

Reimer PJ, Baillie MGL, Bard E, Bayliss A, Beck JW, Bertrand CJH, Blackwell PG, Buck CE, Burr GS, Cutler KB, Damon PE, Edwards RL, Fairbanks RG, Friedrich M, Guilderson TP, Hogg AG, Hughen KA, Kromer B, McCormac G, Manning S, Bronk Ramsey C, Reimer RW, Remmele S, Southon JR, Stuiver M, Talamo S, Taylor FW, van der Plicht J, Weyhenmeyer CE. 2004. IntCal04 terrestrial radiocarbon age calibration, 0-26 cal kyr BP. Radiocarbon 46(3):1029-58.

Robinson E, Smith E. 1841. Biblical Researches in Palestine, Mount Sinai and Arabia Petraea. A Journal of Travels in the Year 1838. Boston: Crocker and Brewster. 620 p.

Rosen S. 1994. Archaeological Survey of Israel: Map of Makhtesh Ramon (204). Jerusalem: The Department of Antiquities and Museums and the Archaeological Survey of Israel.

Rosen S. 2002. Book review, The Wilderness of Zin, Woolley CL, Lawrence TE, Revised edition 2003, Eisenbrauns, Winona Lake. Near Eastern Archaeology 65(4):286-7.

Rothenberg B. 1972. Timna, Valley of the Biblical Copper Mines. London: Thames and Hudson. 248 p.

Rothenberg B, editor. 1988. The Egyptian Mining Temple at Timna. London: Institute for Archaeo-Metallurgical Studies (IAMS), University College London.

Rothenberg B. 1999. Archaeo-metallurgical researches in the southern Arabah 1959-1990. Part 2: Egyptian New Kingdom (Ramesside) to Early Islam. Palestine Exploration Quarterly 131:150-76.

Rowlands J. 1845. Letter. In: Williams G. The Holy City. London: John W Parker. p 463-8.

Shanks H, Dever WG, Halpern B, McCarter Jr PK. 1992. The Rise of Ancient Israel. Washington, DC: Biblical Archaeology Society. $166 \mathrm{p}$.

Sharon I, Gilboa A, Jull AJT, Boaretto E. 2007. Report on the first stage of the Iron Dating Project in Israel: sup- 
porting a Low Chronology. Radiocarbon 49(1):1-46. Stager LE. 1998. Forging an identity: the emergence of ancient Israel. In: Coogan MD, editor. The Oxford History of the Biblical World. New York: Oxford University Press. p 90-131.

Stuiver M, Reimer PJ, Bard E, Beck JW, Burr GS, Hughen KA, Kromer B, McCormac G, van der Plicht J, Spurk M. 1998. IntCal98 radiocarbon age calibration, 24,000-0 cal BP. Radiocarbon 40(3):1041-83.

Trumbull HC. 1884. Kadesh-Barnea. Its Importance and Probable Site with the Story of a Hunt for It. London: Hodder and Stoughton.

van der Plicht J, Bruins HJ. 2001. Radiocarbon dating in Near-Eastern contexts: confusion and quality control. Radiocarbon 43(3):1155-66.

van der Plicht J, Wijma S, Aerts AT, Pertuisot MH,
Meijer HAJ. 2000. Status report: the Groningen AMS facility. Nuclear Instruments and Methods B 172(14):58-65.

Von Raumer K. 1831. Palästina. Mit einem Plan von Jerusalem zur Zeit der Zerstörung durch Titus und dem Grundriss der Kirche des heiligen Grabes. Leipzig: FA Brockhaus. 773 p. In German.

Weinstein JM. 1984. Radiocarbon dating in the southern Levant. Radiocarbon 26(3):297-366.

Wilkinson TJ. 2003. Archaeological Landscapes of the Near East. Tucson: University of Arizona Press. $260 \mathrm{p}$.

Woolley CL, Lawrence TE. 1914-1915. The Wilderness of Zin. Palestine Exploration Fund, Annual. London: Harrison and Sons. Reprinted 2003. London: Palestine Exploration Fund and Stacey International. 